Олег Рибчук,

Національний університет оборони України імені Івана Черняховського ORCID ID 0000-0003-3966-8326

\title{
РОЗВИТОК ФАХОВОЇ КОМПЕТЕНТНОСТІ ВИКЛАДАЧІВ СПЕЦІАЛЬНИХ ДИСЦИПЛІН ВВНЗ У СИСТЕМІ ПІСЛЯДИПЛОМНОЇ ОСВІТИ: РЕЗУЛЬТАТИ ЕКСПЕРИМЕНТАЛЬНОГО ДОСЛІДЖЕННЯ
}

Статтю присвячено висвітленню результатів експериментального дослідження розвитку фахової компетентності викладачів спеціальних дисциплін ВВНЗ у системі післядипломної освіти. Представлено методику проведення та основні результати констатувального $i$ формувального етапів експерименту. Здійснено аналіз та статистичну перевірку достовірності отриманих емпіричних даних. Наукова новизна полягає у доведенні дієвості запровадження в освітній процес курсів перепідготовки та підвищення кваліфікації науково-педагогічних працівників обтрунтованих організаційнопедагогічних умов, щзо передбачають мотивування викладачів до розвитку та саморозвитку, педагогічне моделювання даного процесу, диференціацію змісту і методів розвитку фахової компетентності, запровадження дистанційного курсу для викладачів спеціальних дисциплін. Дані дослідження засвідчили значний особистісний потенціал викладачів спеціальних дисциплін у розвитку їх фахової компетентності, підтвердили вплив на них не випадкових чинників, а запропонованих новацій.

Ключові слова: викладачі спеціальних дисииплін; дослідження; експеримент; фахова компетентність; критерій; організаџійно-педагогічні умови.

Постановка проблеми у загальному вигляді. Розвиток стратегічного партнерства України з НАТО, реформування Збройних сил України, перехід на нові стандарти підготовки та застосування військ (сил) вимагають підвищення якості підготовки офіцерів у військових вишах. Професіоналізацію сил оборони визначено однією 3 пріоритетних цілей оборонної реформи України. Військова освіта має набути практичного спрямування, забезпечити впровадження в освітній процес ВВНЗ передових методик підготовки збройних сил держав - членів НАТО, а також технології дистанційного навчання [1]. Саме викладачі спеціальних дисциплін мають стати рушійною силою запровадження інновацій у військовій освіті, забезпечити подальший розвиток збройних сил. Їх фахова компетентність $\epsilon$ визначальною умовою та безпосередньо позначається на якості підготовки військових фахівців.

Аналіз останніх досліджень і публікацій. Питанням професійного розвитку викладачів закладів вищої освіти присвячено низка експериментальних досліджень, зокрема: експериментальній перевірці ефективності комплексу педагогічних умов, форм і технологій професійного саморозвитку викладачів фахових дисциплін аграрних ВНЗ виконано дослідження В. Ільчук [2, с. 155-191]; перевірці навчально-методичного забезпечення процесу формування у майбутніх викладачів готовності до розв'язування та використання педагогічних задач - Н. Дяченко [3, с. 133158]; Л. Фамілярська здійснила експериментальне дослідження ефективності 
розвитку інформаційно-комунікаційної мобільності педагога у післядипломній освіті [4, с. 133-158]; В. Гусак провела експериментальну перевірку ефективності моделі розвитку професійної компетентності педагога-організатора [5, с. 155-217] та інші.

Вдосконаленню педагогічної компетентності викладачів військових вишів присвячені педагогічні дослідження І. Чистовської [6, с. 10-15], щодо експериментальної перевірки технології особистісно орієнтованої технології формування педагогічної компетентності майбутніх магістрів військового управління, Н. Замотаєвої [7, с. 11-17], яка здійснила перевірку ефективності теоретичної моделі розвитку культуротворчої компетентності викладачів гуманітарних дисциплін ВВНЗ у порівнянні із традиційною методикою.

Однак, проблема розвитку фахової компетентності викладачів спеціальних дисциплін ВВНЗ у системі післядипломної освіти раніше не була предметом окремого експериментального педагогічного дослідження.

Мета дослідження. Мета експериментального дослідження полягала в апробації організаційно-педагогічних умов розвитку фахової компетентності викладачів спеціальних дисциплін ВВНЗ у системі післядипломної освіти.

Методи дослідження. Під час експерименту застосовувався комплекс емпіричних методів дослідження: спостереження, анкетування та бесіди для з'ясування думок і ставлень експертів щодо сучасного стану розвиненості фахової компетентності у викладачів спеціальних дисциплін вищих військових навчальних закладів та визначення проблем у їхній педагогічній діяльності; тестування («Модифікований опитувальник Локус-контролю» О. Ксенофонтової», методика «Ціннісні орієнтації» М. Рокича, методика «Інтелектуальна лабільність», методика «Стильова саморегуляція поведінки людини» В. Моросанової, Е. Коноз, тест «Вольові якості», методика «Оцінка комунікативних та організаторських здібностей», тест «Самооцінка особистості») та анкетування 3 метою з'ясування рівнів розвиненості фахової компетентності викладачів спеціальних дисциплін ВВНЗ. Для опрацювання й теоретичного обгрунтування достовірності результатів дослідження, а також встановлення кількісних залежностей між явищами, що вивчалися застосовувалися статистичні методи аналізу отриманих емпіричних та експериментальних даних (T-критерій Вілкоксона, $U$-критерій Манна Вітні).

Виклад основного матеріалу дослідження. Невід'ємною складовою педагогічного дослідження $є$ педагогічний експеримент, що передбачає об'єктивне оцінювання досліджуваного явища, його кількісне вираження та порівняння. Успішне вирішення проблеми розвитку фахової компетентності викладачів спеціальних дисциплін значною мірою залежить від правильного визначення рівнів розвиненості їх фахової компетентності. Взятий до уваги проаналізований досвід та запропоновані підходи вітчизняних та зарубіжних вчених, дозволили визначили наступну систему критеріїв оцінювання рівнів розвиненості фахової компетентності: ціннісно-мотиваційний, когнітивний, 
емоційно-вольовий, праксеологічний, контрольно-оцінний i суб'єктний [8, c. 286].

На основі узагальнення педагогічних досліджень встановили три рівні розвиненості фахової компетентності викладачів спеціальних дисциплін ВВНЗ: базовий; достатній; високий [8, с. 290].

Емпіричне дослідження проводилося на етапі констатувального та формувального експериментів.

Констатувальний експеримент проводився у період з 2016 по 2017 роки на базі: Національного університету оборони України імені Івана Черняховського (м. Київ), Національної академії сухопутних військ імені гетьмана Петра Сагайдачного (м. Львів), Харківського національного університету повітряних сил імені Івана Кожедуба (м. Харків), Військової академії (м. Одеса).

Дослідження здійснювалося з урахуванням змісту та структури фахової компетентності шляхом анкетування викладачів спеціальних дисциплін ВВН3, а також з використанням психологічних тестових методик.

В анкетуванні взяли участь 216 викладачів спеціальних дисциплін ВВН3 та 24 експерти. Загальна кількість учасників констатувального експерименту складає 240 респондентів.

При заповненні анкети для викладачів спеціальних дисциплін за визначеними показниками діапазон абсолютних значень $\left(2 \leq P_{a б c} \leq 5\right)$ визначається усіма можливими комбінаціями цифр на оцінній шкалі (де найвищий бал, що відповідає еталонному рівню розвиненості показника дорівнював 5, найнижчий, що відповідає відсутності прояву показника дорівнював 2, решта відповідно у діапазоні від 2 до 5). Для зручності порівняння оцінок з результатами тестових методик, які містять інші шкали

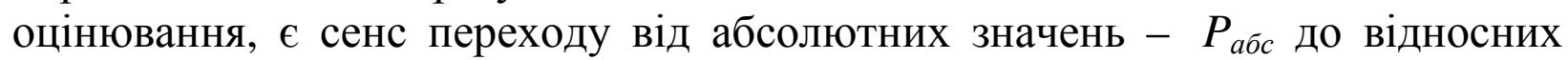
коефіцієнтів - $P_{\text {вid }}\left(0 \leq P_{\text {вid }} \leq 1\right)$, що зумовлено необхідністю унормування кількісних показників відповідно до прийнятого підходу при обробленні даних оцінювання рівнів розвиненості фахової компетентності викладачів спеціальних дисциплін ВВНЗ. Наведені формула (1) дозволяє зробити такий перехід.

$$
P_{\text {вid }}=\frac{P_{a б c}-2}{3}
$$

Рівень розвиненості компоненту розраховувався за формулою 2:

$$
K_{i}=\left(\sum_{j=1}^{n} P_{i j} k_{i j}\right) * 100
$$

де: $K_{i}$ - рівень розвиненості компоненту фахової компетентності за $i$ тим критерієм,

$P_{i j}-j$-тий показник $i$-го критерію,

$n$ - кількість показників $i$-го критерію, 
$k_{i j}$ - ваговий коефіцієнт $j$-того показника $i$-го критерію,

Вагові коефіцієнти $\left(k_{i j}\right)$ кожного показника визначалися методом експертних оцінок.

У результаті констатувального експерименту вдалося встановити значення рівнів розвиненості компонентів фахової компетентності викладачів спеціальних дисциплін ВВНЗ [9, с. 72-73].

Визначення інтегрального рівня розвиненості фахової компетентності викладачів спеціальних дисциплін ВВНЗ проводилося за формулою 3:

$$
K_{\Sigma}=\frac{K_{u, n}+K_{\kappa}+K_{e b}+K_{n}+K_{\kappa o}+K_{c}}{6}
$$

де $K_{u м}$ - результати оцінювання ціннісно-мотиваційного компоненту;

$K_{\kappa}$ - результати оцінювання когнітивного компоненту;

$K_{e \varepsilon}$ - результати оцінювання емоційно-вольового компоненту;

$K_{n}$ - результати досліджуваних праксеологічного компоненту;

$K_{\kappa o}$ - результати оцінювання контрольно-оцінного компоненту;

$K_{c}$ - результати оцінювання суб' єктного компоненту.

Значення інтегрального показника розвиненості фахової компетентності на етапі констатувального експерименту становить $K_{\Sigma}=69,6 \%$.

Визначення інтегральних показників розвиненості фахової компетентності досліджуваних викладачів дозволив розподілити їх за відповідними рівнями:

- високий рівень - 32 викладачі / 14,8\%;

- достатній рівень - 96 викладачів / 44,4\%;

- базовий рівень - 88 викладачів / 40,8\%.

За підсумками констатувального етапу експерименту вдалося визначити низку нагальних проблем, що потребують теоретичного осмислення і на цій основі розроблення відповідних методичних рекомендацій щодо організації формувального етапу експерименту [9, с. 74-75].

На другому етапі, під час формувального експерименту, що проводився упродовж 2017 - 2018 років, здійснювалась апробація організаційнопедагогічних умов розвитку фахової компетентності [10, с. 112-114], реалізація професійно орієнтованої структурно-функціональної моделі, діагностування розвиненості фахової компетентності військових педагогів через визначені компоненти.

Експериментальною базою виступили навчальні групи курсів перепідготовки та підвищення кваліфікації для науково-педагогічних працівників Національного університету оборони України імені Івана Черняховського. Було визначено дві контрольні групи (КГ1 та КГ2) та дві експериментальні групи (ЕГ1 та ЕГ2) (по одній КГ та ЕГ на курсах 3 терміном проведення до одного місяця та по одній КГ та ЕГ на курсах 3 терміном проведення до трьох місяців). Загальна чисельність викладачів спеціальних дисциплін у групах, що залучалися до дослідження на цьому етапі склала 47 осіб.

Аналіз результатів діагностування за показниками та критеріями 
фахової компетентності дозволив встановити деякі особливості. Зокрема важливим елементом розгляду мотиваційного компонента фахової компетентності $є$ дослідження спрямованості особистості, що вказує напрямок активності особистості.

Діагностування спрямованості викладачів спеціальних дисциплін вказує на те, що пріоритети для досліджуваних розташувались наступним порядком: спрямованість на себе - значення медіани 32 ; спрямованість на справу - 26; спрямованість на взаємодію - 22. Переважаючі тенденції спрямованості викладачів спеціальних дисциплін розподілилися наступним чином (викладачів / \%): спрямованість на себе - КГ1 3/23,1; ЕГ1 2/16,7; КГ2 2/20; ЕГ2 8/66,7; спрямованість на справу - КГ1 6/46,2; ЕГ1 5/41,7; КГ2 6/60; ЕГ2 3/25; спрямованість на взаємодію - КГ1 4/30,8; ЕГ1 5/41,7; КГ2 2/20; ЕГ2 $1 / 8,3$.

3 отриманих даних можемо констатувати, що у викладачів спеціальних дисциплін виражені тенденції спрямовані на досягнення особистих цілей у власній діяльності, прагнення переваг та престижу, орієнтація на винагороду, переоцінка статусних цінностей у професії викладача. Відзначаємо домінування власних інтересів та інтересів справи вище інтересів тих хто вчиться (слухачів, курсантів). Очевидно, що така позиція не $є$ найкращою для викладача вищої військової школи.

Великого значення у структурі ціннісно-мотиваційного компоненту фахової компетентності набувають мотиви досягнення успіху та уникнення невдач. Діагностування показало, що тільки $33,2 \%$ - 15 викладачів мають перевагу у мотивації досягнення успіху, ще 44,7\% - 21 особа - мають однакові показники рівнів мотивації досягнення успіху та мотивації уникнення невдач, а $21,1 \%$ - 11 викладачів спеціальних дисциплін мають перевагу у мотивації уникнення невдач.

Варто зазначити, що за умови домінування мотиву досягнення успіху, особистості притаманні наступні особистісні характеристики: сприйняття ситуації досягнення успіху як невід'ємної та звичайної складової життєдіяльності; впевненість у власних діях та успішному результаті; готовність i здатність брати на себе відповідальність у ситуації невизначеності; готовність братися за справи середньої та високої складності; інтенсивність зусиль в досягненні намічених цілей; високий рівень домагань після успіху, та інше.

Відтак, мотив досягнення успіху забезпечує високий рівень активності, спонукає до пошуку нових способів діяльності, вивільнення власної енергії, здібностей, сил. Натомість високий рівень мотивації уникнення невдач впливає на поведінку так, що людина не буде проявляти ініціативу, буде коритися вимогам ситуації. За таких умов, фахівець ставить перед собою легкі або дуже складні цілі, успіх чи неуспіх у досягненні яких не впливатиме на самооцінку. У разі постановки реальних цілей буде шукати зовнішньої допомоги та підтримки, відволікаючись від діяльності.

Детальний аналіз результатів діагностування когнітивного компоненту 
дозволив встановити напрямки підготовки викладачів спеціальних дисциплін, за якими вони відчувають найбільший брак знань у їх реалізації: педагогічне цілепокладання, а саме: визначати шляхи освіти, розвитку, виховання й моральної підготовки курсантів (37 осіб / 78,7\%); формулювати результати підготовки курсантів у вигляді компетентностей (32 особи / $68,1 \%)$; педагогічне прогнозування - прогнозувати особистісний розвиток кожного слухача (курсанта) (31 особа / 66,0\%); виявляти можливі відхилення у розвитку й поведінці курсанта при відповідному впливі (38 осіб / 80,9\%); теоретико-методологічне забезпечення викладання навчальної дисципліни опиратися на положення, висновки, закономірності й концепції педагогічної теорії вищої військової школи (41 особа / 87,2\%); розглядати об'єкт, проблему, які вивчаються у цілісності, їх зв'язків і характеристик (38 осіб / 80,9\%); методичне забезпечення викладання навчальної дисципліни синтезувати знання 3 психології, педагогіки й методики викладання дисципліни (35 осіб / 74,5\%); інформаційне забезпечення викладання навчальної дисципліни - осмислювати роль кожного елементу у структурі навчального заняття та у взаємодії з іншими (31 особа / 66,0\%); педагогічна діагностика - виявляти педагогічні явища i встановлювати між ними причинно-наслідкові в'язки (34 особи / 72,3\%); визначати рівень розвиненості психічних пізнавальних процесів у кожного курсанта (41 особа / 87,2\%); контрольно-аналітична діяльність - виявляти причинно-наслідкові зв’ язки у навчанні й вихованні курсантів (28 осіб / 72,3\%).

Можемо констатувати, що отримані низькі оцінки психологопедагогічних знань $є$ прогнозованими, оскільки програми підготовки офіцерів тактичного та оперативно-тактичного рівнів - майбутніх викладачів спеціальних дисциплін, не містять дисциплін спрямованих на педагогічну підготовку слухачів (курсантів).

Отримані результати дослідження емоційно-вольового компоненту дають можливі зробити висновки щодо особливостей саморегуляції викладачів спеціальних дисциплін. Інтерпретуючи результати дослідження дотримувались позиції, що серед професійних якостей військового педагога важливе значення мають індивідуальний стиль саморегуляції та вольові якості. Вони дають змогу викладачу опанувати себе у складних моментах професійної діяльності, продуктивно вирішувати різноманітні проблеми.

Аналіз результатів діагностування загального рівня саморегуляції показав, що 12 викладачів / 25,5\% мають високий рівень іiі розвиненості, 34 викладача / 72,3\% респондентів - середній рівень. Порівнюючи зі значенням медіани, що складає $M e=28$ стенів (при $Q=5$ ), яке відповідає достатньому рівню розвиненості емоційно-вольової саморегуляції (базовий < 23; достатній 24-32; високий > 33), можна зазначити, що отримані викладачами значення їх саморегуляції знаходяться на достатньому рівні.

Однак, враховуючи спадаючу динаміку показників саморегуляції у групах викладачів які мають більший педагогічний стаж вважаємо, що існує потреба у розвитку навичок свідомої саморегуляції поведінки й діяльності 
викладачів спеціальних дисциплін задля зниження залежності від впливу на них обставин та середовища. Чим вищий рівень усвідомленої саморегуляції суб'єкта військово-педагогічної діяльності, тим швидше він опановує новий вид активності, успішно діє як у нестандартних ситуаціях та і у звичних видах діяльності.

Одержані результати дають змогу прогнозувати високу здатність викладачів спеціальних дисциплін ВВНЗ до пристосування та емоційного корегування власних станів під час організації та здійснення освітнього процесу. Проте, під час підвищення педагогічної кваліфікації у системі післядипломної освіти слід проводити індивідуальну роботу психокорекції із викладачами, які мають низькі показники розвиненості вольових здібностей та емоційно-вольової саморегуляції.

Аналіз результатів дослідження праксеологічного компоненту дозволив прийти до висновку, що викладачі спеціальних дисциплін відчувають найбільше труднощів у діагностичній (базовий рівень 13 осіб / 27,7\%; достатній рівень 34 особи / 72,3\%) та управлінській (базовий рівень 12 осіб / $25,5 \%$; достатній рівень 35 осіб / 74,5\%) діяльності, а також у групах 3 педагогічним стажем до 3-х років (КГ2, ЕГ2) - в організації наукових досліджень (базовий рівень 7 осіб / 31,8\%; достатній рівень 22 особи / 68,2\%). Дослідження засвідчило достатній рівень розвиненості дидактичних (базовий рівень 7 осіб / 14,9\%; достатній рівень 36 осіб / 76,6\%; високий рівень 4 особи / 8,5\%), виховних (базовий рівень 5 осіб / 10,6\%; достатній рівень 40 осіб / 85,1\%; високий рівень 2 особи / 4,3\%) та методичних (базовий рівень 4 особи / 8,5\%; достатній рівень 41 особа / 87,2\%; високий рівень 2 особи / 4,3\%) умінь більшості викладачів спеціальних дисциплін як контрольних, так і експериментальних груп; встановлено дещо вищий рівень розвиненості організаційних вмінь викладачів (базовий рівень 8 осіб / 17,0\%; достатній рівень 11 осіб / 23,4\%; високий рівень 28 осіб / 59,6\%); найбільш розвиненими виявилися комунікативні вміння викладачів у всіх групах (базовий рівень 7 осіб / 14,9\%; достатній рівень 11 осіб / 23,4\%; високий рівень 29 особи / 61,7\%).

За результатами діагностування встановлено, що відмінності між відповідними групами на початку формувального експерименту не були значущими, а інтегральний показник розвиненості ФК становив у КГ1 $68,7 \%, \mathrm{E} \Gamma 1-69,7 \%$, КГ $2-68,1 \%, \mathrm{E} Г 2-68,9 \%$ за умови $p \leq 0,05$ (табл. 1 ).

Експериментальне навчання проводилось у реальних умовах освітнього процесу, при цьому в експериментальних групах здійснювався експериментальний педагогічний вплив. Він полягав у запровадженні в освітній процес визначених організаційно-педагогічних умов, а саме було проведено комплекс практичних занять, суть яких полягала у створенні та розв'язанні проблемних педагогічних завдань та залучені викладачів експериментальних груп до проходження дистанційного курсу «Фахова компетентність викладачів спеціальних дисциплін ВВНЗ». Водночас загальний час аудиторної роботи не збільшився. 
Інтегральний показник рівнів розвиненості фахової компетентності на початку формувального експерименту

\begin{tabular}{|c|c|c|c|c|c|}
\hline \multirow{3}{*}{$\begin{array}{l}\text { № } \\
\text { 3/II }\end{array}$} & \multirow{3}{*}{$\begin{array}{l}\text { Результати } \\
\text { оцінювання }\end{array}$} & \multicolumn{4}{|c|}{ На початку формувального експерименту } \\
\hline & & \multicolumn{2}{|c|}{ КГ } & \multicolumn{2}{|c|}{$\mathbf{E \Gamma}$} \\
\hline & & КГ1 & $\mathbf{K Г 2}$ & EГ1 & EГ2士 \\
\hline 1 & $K_{u, M}(\%)$ & 63,2 & 62,3 & 64,2 & 63,3 \\
\hline 2 & $K_{K}(\%)$ & 76,5 & 74,5 & 77,8 & 74,8 \\
\hline 3 & $K_{e B}(\%)$ & 69,5 & 75,6 & 69,5 & 73,2 \\
\hline 4 & $K_{n}(\%)$ & 78,8 & 72,3 & 78,1 & 73,2 \\
\hline 5 & $K_{\kappa o}(\%)$ & 52,7 & 52,2 & 53,8 & 58,0 \\
\hline 6 & $K_{c}(\%)$ & 71,3 & 71,8 & 74,6 & 70,7 \\
\hline 7 & $\boldsymbol{K}_{\Sigma}$ & 68,7 & 68,1 & 69,7 & 68,9 \\
\hline
\end{tabular}

За умови $p \leq 0,05$

За результатами підсумкового діагностування інтегральний показник розвиненості ФК становив у КГ $1-72,8 \%$, ЕГ $1-83,1 \%$, КГ $2-73,9 \%$, ЕГ2 $84,3 \%$ за умови $p \leq 0,05$ (табл. 2). Найбільш суттєвих позитивних змін вдалося досягнути в експериментальних групах у ціннісно-мотиваційному компоненті (ЕГ1 на 16,7\%; ЕГ2 на 25,5\%), когнітивному компоненті (ЕГ2 на $12,5 \%$ ), емоційно-вольовому компоненті (ЕГ1 на 18,6\%), суб’єктному компоненті (ЕГ1 на 15,4\%; ЕГ2 на 15,7\%). Отримані дані свідчать про значний особистісний потенціал викладачів спеціальних дисциплін у розвитку їх фахової компетентності.

Таблиия 2

Інтегральний показник рівнів розвиненості фахової компетентності у кінці формувального експерименту

\begin{tabular}{|c|c|c|c|c|c|}
\hline \multirow{3}{*}{$\begin{array}{l}\text { № } \\
\text { 3/II }\end{array}$} & \multirow{3}{*}{$\begin{array}{l}\text { Результати } \\
\text { оцінювання }\end{array}$} & \multicolumn{4}{|c|}{ У кінці формувального експерименту } \\
\hline & & \multicolumn{2}{|c|}{$\mathbf{K} \boldsymbol{\Gamma}$} & \multicolumn{2}{|c|}{$\mathbf{E} \boldsymbol{\Gamma}$} \\
\hline & & КГ1 & КГ2 & EГ1 & EГ2士 \\
\hline 1 & $K_{u, M}(\%)$ & 69,0 & 70,4 & 80,9 & 88,8 \\
\hline 2 & $K_{\kappa}(\%)$ & 82,7 & 79,6 & 90,6 & 90,5 \\
\hline 3 & $K_{e B}(\%)$ & 73,6 & 80,6 & 88,1 & 85,4 \\
\hline 4 & $K_{n}(\%)$ & 81,0 & 77,4 & 86,0 & 85,7 \\
\hline 5 & $K_{\kappa O}(\%)$ & 53,6 & 57,3 & 63,4 & 68,9 \\
\hline 6 & $K_{c}(\%)$ & 76,7 & 77,9 & 90,0 & 86,4 \\
\hline 7 & $\boldsymbol{K}_{\Sigma}$ & 72,8 & 73,9 & 83,1 & 84,3 \\
\hline
\end{tabular}

За умови $p \leq 0,05$

Динаміка змін інтегрального показника зображена на рисунку 1.

Оцінювання рівнів розвиненості ФК викладачів спеціальних дисциплін здійснювалося шляхом визначення середнього рівня підготовленості групи (математичного очікування підготовки групи $-\bar{X}$ ), що визначає відсоток досягнутого результату, що був отриманий групою у середньому від загального необхідного рівня (еталону). 


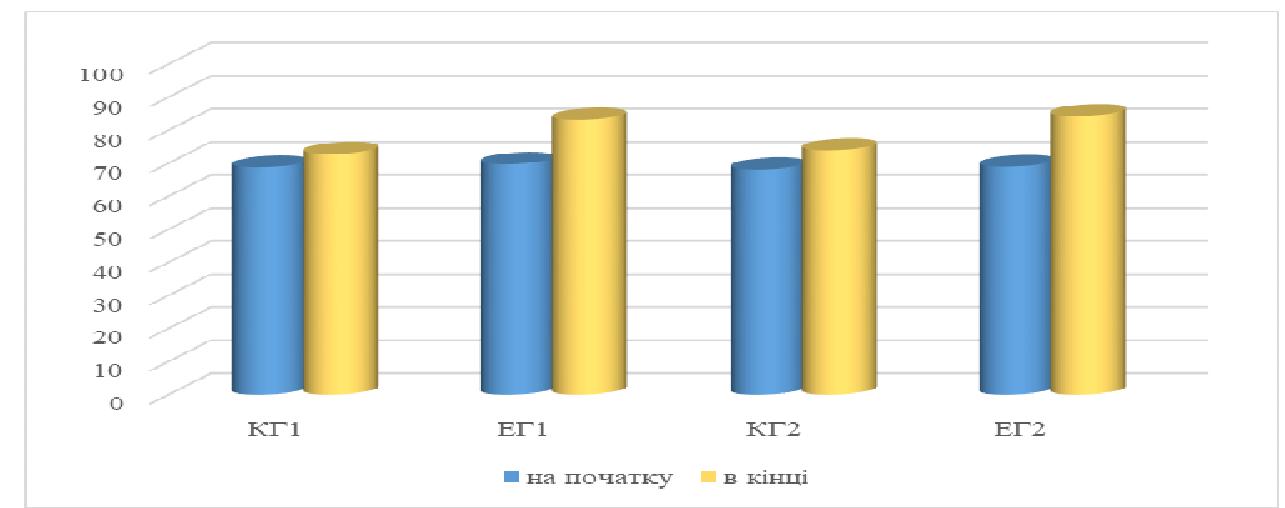

Рис. 1 Динаміка змінн інтегрального показника рівня розвиненості ФК викладачів спеціальних дисциплін

Перевірка статистичної значущості одержаних результатів за допомогою критерію Манна - Вітні $U$ та критерію $T$ Вілкоксона дозволила встановити позитивні значущі зміни в експериментальних групах та відсутність значущих змін у контрольних групах, що засвідчує вплив на викладачів спеціальних дисциплін не випадкових чинників, а запропонованих новацій. Таким чином, у ході формувального експерименту доведено результативність впровадження в освітній процес обгрунтованих організаційно-педагогічних умов.

Висновки. За для експериментальної перевірки організаційнопедагогічних умов розвитку фахової компетентності викладачів спеціальних дисциплін ВВНЗ у системі післядипломної освіти проведено експериментальне дослідження яке включало констатувальний і формувальний етапи.

На констатувальному етапі експерименту було обрано експериментальну базу дослідження, обгрунтовано кількість досліджуваних та експертів, обрано діагностичний інструментарій, проаналізовано й узагальнено стан розвиненості фахової компетентності викладачів спеціальних дисциплін ВВНЗ, визначено контрольні та експериментальні групи. На формувальному - запроваджено в освітній процес визначених організаційно-педагогічних умов, проведено контрольне діагностування на початку та у кінці цього етапу.

За результатами діагностування встановлено, що відмінності між відповідними групами на початку формувального експерименту не були значущими. Експериментальне дослідження проводилось у реальних умовах освітнього процесу, при цьому в експериментальних групах здійснювався експериментальний педагогічний вплив.

Підсумкове діагностування засвідчило підвищення значень інтегрального показника розвиненості ФК, при цьому в експерементальлних групах зміни були на рівні статистичної значимості, натомість у контрольних групах статистично значущих змін не відбулося. Найбільш суттєвих позитивних змін вдалося досягнути в експериментальних групах у ціннісномотиваційному (ЕГ1 на 16,7\%; ЕГ2 на 25,5\%), когнітивному (ЕГ2 на 12,5\%), емоційно-вольовому (ЕГ1 на 18,6\%) і суб' єктному компонентах (ЕГ1 на $15,4 \%$; ЕГ2 на 15,7\%). Отримані дані свідчать про значний особистісний потенціал викладачів спеціальних дисциплін у розвитку їх фахової 
компетентності, засвідчують вплив на них не випадкових чинників, а запропонованих новацій. Таким чином, у ході експерименту доведено результативність впровадження в освітній процес обгрунтованих організаційно-педагогічних умов.

\section{ЛІТЕРАТУРА}

1. Стратегічний оборонний бюлетень України. Указ президента України № 240/2016 URL : https : // www.president.gov.ua (дата звернення 06.11.2018).

2. Ільчук В. В. Педагогічні умови професійного саморозвитку викладачів фахових дисциплін у вищих аграрних навчальних закладах : дис. ... канд. пед. наук : 13.00.04. Київ, 2016. 254 c.

3. Дяченко Н. О. Формування вмінь розв'язувати педагогічні задачі у майбутніх викладачів педагогіки на магістерському рівні: дис. ... кандидата пед. наук : 13.00.04. Київ, 2015. 189 c.

4. Фамілярська Л. Л. Розвиток інформаційно-комунікаційної мобільності педагога в освітньому середовищі післядипломної освіти : дис. ... канд. пед. наук : 13.00.04. Житомир, 2017. 292 с.

5. Гусак В. М. Розвиток професійної компетентності педагога-організатора в умовах післядипломної освіти : дис. ...канд. пед. наук : 13.00.04. Житомир, 2018. 256 с.

6. Чистовська I. П. Формування педагогічної компетентності майбутніх магістрів військового управління: автореферат дис. ... канд. пед. наук: 13.00.04. Київ, 2006. 20 с.

7. Замотаєва Н. В. Розвиток культуротворчої компетентності викладачів гуманітарних дисциплін вищих військових навчальних закладів із використанням кейстехнології : автореферат дис. ... канд. пед. наук : 13.00.04. Київ, 2017. 25 с.

8. Рибчук О. О. Критерії, показники оцінювання рівнів розвиненості фахової компетентності викладачів спеціальних дисциплін ВВНЗ. Освіта дорослих: теорія, досвід, перспективи : зб. наук. пр. Ін-т пед. освіти і освіти дорослих НАПН України, Київ, 2017. Вип. 1 (13). С. 282-291.

9. Рибчук О., Зельицький А. Викладачі спеціальних дисциплін ВВНЗ: стан підготовленості та напрями іiі удосконалення. Військова освіта : зб. наук. пр. Національного університету оборони України імені Івана Черняховського. Київ, 2017. № 2 (36). С. 69-76.

10. Рибчук О. О. Організаційно-педагогічні умови розвитку фахової компетентності викладачів спеціальних дисциплін ВВНЗ у системі післядипломної освіти. Науковий вісник Мукачівського державного університету. Серія: «Педагогіка та психологія» : зб. наук. пр., Мукачеве, 2017. Вип. 2 (6). С. 111-114.

\section{REFERENCES}

1. Stratehichnyi oboronnyi biuleten Ukrainy. [The Strategic Defense Bulletin of Ukraine] Ukaz prezydenta Ukrainy № 240/2016 URL : https : // www.president.gov.ua (data zvernennia 06.11.2018). (in Ukrainian).

2. Ilchuk, V. V. (2016) Pedahohichni umovy profesiinoho samorozvytku vykladachiv fakhovykh dystsyplin u vyshchykh ahrarnykh navchalnykh zakladakh [Pedagogical conditions of professional self-development of teachers of professional disciplines in higher agricultural educational institutions]: dys. ...kandydata ped. nauk: 13.00.04. Kyiv, 254 s. (in Ukrainian).

3. Diachenko, N. O. Formuvannia vmin rozviazuvaty pedahohichni zadachi u maibutnikh vykladachiv pedahohiky na mahisterskomu rivni [Formation of skills to solve pedagogical problems of future teachers of pedagogy at the master's level]: dys. ...kandydata ped. nauk: 13.00.04. Kyiv, 2015. 189 s. (in Ukrainian).

4. Familiarska, L. L. (2017) Rozvytok informatsiino-komunikatsiinoi mobilnosti pedahoha $\mathrm{v}$ osvitnomu seredovyshchi pisliadyplomnoi osvity [Development of information and 
communication mobility of the teacher in the educational environment of postgraduate education]: dys. ...kandydata ped. nauk: 13.00.04. Zhytomyr, 292 s. (in Ukrainian).

5. Husak, V. M. (2018) Rozvytok profesiinoi kompetentnosti pedahoha-orhanizatora $v$ umovakh pisliadyplomnoi osvity [Development of professional competence of the teacherorganizer in the conditions of postgraduate education]: dys. ...kandydata ped. nauk: 13.00.04. Zhytomyr, 256 s. (in Ukrainian).

6. Chystovska, I. P. (2006) Formuvannia pedahohichnoi kompetentnosti maibutnikh mahistriv viiskovoho upravlinnia [Formation of pedagogical competence of future masters of military management]: avtoreferat dys. ...kandydata ped. nauk: 13.00.04. Kyiv, 20 s. (in Ukrainian).

7. Zamotaieva, N. V. (2017) Rozvytok kulturotvorchoi kompetentnosti vykladachiv humanitarnykh dystsyplin vyshchykh viiskovykh navchalnykh zakladiv iz vykorystanniam keistekhnolohii [Development of cultural competence of teachers of humanitarian disciplines of higher military educational institutions using case-technology]: avtoreferat dys. ...kandydata ped. nauk: 13.00.04. Kyiv, 25 s. (in Ukrainian).

8. Rybchuk, O. O. (2017) Kryterii, pokaznyky otsiniuvannia rivniv rozvynenosti fakhovoi kompetentnosti vykladachiv spetsialnykh dystsyplin VVNZ. [Criteria, Showings assessment of levels of Higher Military Educational Institutions special subjects lecturers professional development] Osvita doroslykh: teoriia, dosvid, perspektyvy: zb. nauk. pr. In-t ped. osvity i osvity doroslykh NAPN Ukrainy, Kyiv, Vyp. 1 (13). S. 282-291. (in Ukrainian).

9. Rybchuk, O., Zelytskyi, A. (2017) Vykladachi spetsialnykh dystsyplin VVNZ: stan pidhotovlenosti ta napriamy yii udoskonalennia. [Teachers of special disciplines of higher military schools: state of preparation and directions for its improvement] Viiskova osvita : zb. nauk. pr. Natsionalnoho universytetu oborony Ukrainy imeni Ivana Cherniakhovskoho. Kyiv, № 2 (36). S. 69-76. (in Ukrainian).

10. Rybchuk, O. O. (2017) Orhanizatsiino-pedahohichni umovy rozvytku fakhovoi kompetentnosti vykladachiv spetsialnykh dystsyplin VVNZ u systemi pisliadyplomnoi osvity. [Organizational and pedagogical conditions of the Higher Military Educational Institutions special subjects lecturers professional competence development in post-graduate education system] Naukovyi visnyk Mukachivskoho derzhavnoho universytetu. Seriia: «Pedahohika ta psykholohiia»: zb. nauk. pr., Mukacheve, Vyp. 2 (6). S. 111-114. (in Ukrainian).

\title{
РЕЗЮМЕ
}

Олег Рыбчук

Национальный университет обороны Украины имени Ивана Черняховского

\section{Развитие специальной компетентности преподавателей специальных дисциплин ВВУЗ в системе последипломного образования: результаты экспериментального исследования}

\begin{abstract}
Статья посвящена освещению результатов экспериментального исследования развития специальной компетентности преподавателей специальных дисциплин ВВУЗ в системе последипломного образования. Представлена методика проведения и основные результаты констатирующего и формирующего этапов эксперимента. Осуществлен анализ и статистическая проверка достоверности полученных эмпирических данных. Научная новизна заключается в доведении действенности введения в образовательный процесс курсов переподготовки и повышения квалификаџии научно-педагогических работников обоснованных организачионно-педагогических условий, предусматривающих мотивачию преподавателей к развитию и саморазвитию, педагогическое моделирование данного процесса, дифференциицию содержания и методов развития профессиональной
\end{abstract}


компетентности, внедрение дистанционного курса для преподавателей специальных дисциплин. Данные исследования показали значительный личностный потенциал преподавателей специальных дисииплин в развитии их специальной компетентности, подтвердили влияние на них не случайных факторов, а предложенных новаций.

Ключевые слова: преподаватель специиальных дисчиилін; исследование; эксперимент; специальная компетентность; критерий; организационно-педагогические условия.

\section{SUMMARY}

\section{(O) Rybchuk}

National Defence University of Ukraine named after Ivan Chernyahovskyi

\section{Development of Professional Competence of Lecturers' of Special Courses of HMEI in the Postgraduate Education System : Results of Experimental Research}

Introduction. The present paper deals with results of experimental research of development of professional competence of lecturers' of special courses of HMEI in the postgraduate education system.

Purpose of the paper is to present organizational and pedagogical conditions of development of professional competence of lecturers' of special courses of HMEI in the postgraduate education system.

Methods: observation, questionnaire and conversation in order to figure out points of view and attitude of experts to modern state of professional competence of lecturers' of special courses of HMEI development and to define problems of their teaching activities; testing and questionnaire of lecturers. The statistical methods for obtained empirical and experimental data analysis such as Wilcoxon signed-rank test, Mann-Whitney U-test were used in order to process data and to prove theoretically validity of the research results and also to determine numerical relationships between studied occurrences.

Results proved significant personal potential of lecturers' of special courses in the development of their professional competence and confirmed influence of not random factors, but proposed innovations.

Originality of the paper deals with confirmation of efficiency of justified organizational and pedagogical conditions introduction into educational process of retraining courses and advanced vocational training of academics, which provide motivation of lecturer to development and self-development, pedagogical modeling of this process, differentiation of content and methods of professional competence development, introduction of distant course for lecturers' of special courses.

Conclusion. The research proved efficiency of justified organizational and pedagogical conditions introduction into educational process.

Ключові слова: lecturers of special courses; research; experiment; professional competence; criterion; organizational and pedagogical conditions. 